\title{
Current Status of Mutual Fund Schemes in Nepal
}

\author{
Dhaneshwar Rakhal
}

\begin{abstract}
The development of the mutual fund industry is the greatest investment success story of the twentieth century in United States and this industry also emerged as the most dynamic segment of the Indian financial system on that time. But the history of mutual fund in Nepal started only with the establishment of "NCM Mutual Fund 2050" in 1993. Currently there are ten mutual fund schemes listed and traded in Nepal Stock Exchange that provide investment opportunities for investors in mutual funds market. In this context, the purpose of this paper is to provide necessary facts and figures related to the mutual fund schemes in Nepal based on secondary data. The paper includes mutual fund companies, development mutual funds and review of empirical studies on mutual funds as preliminary discussion, and includes current mutual fund schemes; funds sizes, maturity periods, market price, net asset value and dividend income of mutual fund schemes on analytical section.
\end{abstract}

Keywords: Dividend, fund size, investment company, market price, maturity, mutual funds, net asset value, schemes

\section{Introduction}

Mutual funds are firms that manage pools of other people's money. Individuals buy shares of mutual funds, and the funds invest the money in certain specified types of assets, for example, common stocks, tax-exempt bonds, or mortgages. The shares issued to the investors entitle them to a pro rata portion of the income generated by these assets. Mutual fund holds cash, near-cash, stocks, bonds, other types of marketable securities, and, in some cases, real assets (Bodie, Kane \& Marcus, 1995). The exact composition of the portfolio depends on the type of fund and the investment objective of the fund.

Mutual funds operate like any other business, with a management staff, employees, and facilities. Mutual funds perform several important functions for their shareholders, i.e. recordkeeping and administration, diversification and divisibility, professional management and lower transaction cost (Bodie et al., 995). As corporations, they also have a board of directors. The key employees of a fund are the security analysts and portfolio managers, who develop investment strategies. Larger funds ordinarily have an agreement with an investment adviser. The investment advisor provides services to all the funds in the family on a fee basis and is responsible for research, security analysis, and execution of security transactions, portfolio management, and administrative duties. The fund may also contract with another firm to keep records of transfers of cash and securities and maintain shareholders records. A custodian may be employed to store and safeguard the securities (Cheney \& Moses, 1992). 


\section{Literature Review}

\section{Investment Company}

Investment Company is a type of financial intermediary that sells shares to the investors and invests the obtained money from the investors in a diversified portfolio of securities. Each share that they sell represents a proportionate interest in a portfolio of securities (Fabozzi, 1995). In return, the investors receive certain rights regarding the financial assets that the investment company has bought and any earnings that the company may generate. In the simplest and most common situation, the investment company has only one type of investorstockholders. These stockholders own the investment company directly and own indirectly the financial assets that the company itself owns (Alexander, Sharpe \& Bailey, 2002).

There are several advantages, for an individual in buying shares of investment companies rather than buying investments directly in the market. First, for a given amount of funds, an investor can obtain broader portfolio diversification (Fabozzi, 1995). Suppose if an individual with moderate financial resources wishes to invest in the stock market, in terms of economies of scale, the individual could buy stocks in odd lots to build a diversified portfolio. But the brokerage commissions on odd lot transactions are relatively high. Alternatively, the individual could purchase round lots, but would be able to afford only a few different securities (Alexander et al., 2002). In order to receive the benefits of both diversification and substantially reduce brokerage commissions, the individual could invest in the shares of an investment companies. A purchase or sale of a share of an investment company represents a purchase or sale of a portion of an entire portfolio.

Second, an investor obtains the services of professional money managers at a cost that is less than if an investor hired a money manager directly. Moreover, many management firms would not take a client with less than specified amount to invest, and some firms require a high amount as minimum limits. Third, investment companies offer a more convenient outlet for investing. The purchase or sale of share in an investment company can be done quite easily through a broker. Moreover, the bookkeeping for all transactions is done by the investment company (Fabozzi, 1995).

There are three types of investment companies: Unit investment trust, closed-end investment companies and open-end investment companies. "A unit investment trust is an investment company that owns a fixed set of securities for the life of the company" (Alexander et al., 2002, p. 575). The unit investment trust issues a fixed number of ownership shares, called unit certificates (Fabozzi,1995). The investment company rarely alters the composition of its portfolio during the life of the company.

Closed-end investment company (or closed-end fund) sell shares like any other corporation and usually do not redeem their shares. Shares of closed-end funds sell on either an organized exchange or in the over-the-counter market. Thus, an investor who wants to buy or sell shares of a closed-end fund simply places an order with a broker, just as if the investor wanted to buy or sell shares of other listed companies (Alexander et al., 2002). 
An open-end investment company (or open-end fund), more popularly referred to as mutual fund, continually stands ready to sell new shares to the public and to redeem its outstanding shares on deemed at a price equal to an appropriate share of the value of its portfolio, which is computed daily at the close of the market (Fabozzi,1995). Because of their capitalization is open, the number of shares outstanding also changes on the daily basis. A mutual fund's share price is based on its Net Asset Value (NAV) per share, which is found by subtracting mutual fund's liabilities from the market value of the portfolio and dividing by the number of mutual fund shares outstanding. That is:

$$
\mathrm{NAV}_{\mathrm{t}}=\frac{\mathrm{MVA}_{\mathrm{t}}-\mathrm{LIAB}_{+}}{\mathrm{NSO}_{\mathrm{t}}}
$$

Where MVA $_{t}$, LIAB $_{t}, \mathrm{NSO}_{\mathrm{t}}$ denote the market value of mutual fund's assets, the amount of the mutual fund's liabilities, and the number of shares the mutual fund has outstanding, respectively, as of the end of the day $t$.

\section{Development of Mutual Funds}

The earliest investment fund was a closed-ended fund formed in Netherlands in 1774. In 1868, such fund was formed in Britain and in 1893 in the United States. The first open-ended mutual fund, which could continuously create and cancel units and thus vary its capital, was the Massachusetts Investment Trust created in the United States in 1924 (World Bank, 2015). Mutual fund industry in India dates back to 1963, when Unit Trust of India was formed at the initiative of the Government of India, and Reserve Bank of India. With the entry of numerous Mutual Fund players, and a number of products across asset classes, the industry has come a long way. As of December, 2015, investors in India had an option to choose from more than a thousand Mutual Fund schemes spread across 44 Mutual Funds (Indian Chamber of Commerce, 2016).

The history of mutual fund in Nepal started with the establishment of "NCM Mutual Fund 2050" by Nepal Industrial Development Corporation (NIDC) Capital Market in Ashad 19, 2050 BS (1993). NCM first Mutual Fund 2050 was started with the objectives of providing expert investment services with par value of Rs 10 per unit that was issued in the multiple of 100 by NIDC Capital Market and it was initially open-end type. The term of the NCM Mutual Fund 2050 was completed in 2058 BS (2001) and it was converted into close-end fund in the name of "NCM Mutual Fund, 2059" in 2059 BS (2002). During the termination of NCM Mutual Fund 2050, the fund holders were given option to refund or to participate in another new scheme called "NCM Mutual Fund 2059" The fund had 10 million units outstanding with Rs. 10 par value, and 10 years maturity period (Sharma, Thapa, Pandeya, Joshi \& Lamsal, 2016). The fund was of open-end type in which individuals and organizations could purchase the unit. The units issued under this scheme were listed in Nepal Stock Exchange (NEPSE) in accordance to Securities Exchange Act, 2040. The fund could be involved in shares, debentures, bonds and term loan.

Citizen Unit Scheme (CUS) 2052, with a par value of Rs. 100 came into operation in the year 1995. Citizen Investment Trust (CIT) had been managing this scheme. CIT, a trust company 
registered under Citizen Invest Trust Act 2047, also manages unit scheme. A separate trust committee has been formed to look after the policy matters and operational aspects, where expert representation also from outside the organization. CIT is providing buyback facilities at its own premises to facilitate for liquidity of the units. Securities Board of Nepal regulates the Unit Trust Scheme. Being an open-end fund, the unit of Citizen Unit Scheme could be purchased from and sold to CIT at any time by an individual or an organization (Shrestha, Poudel \& Bhandari, 2005). Therefore, the number of units outstanding varied from time to time. CIT also invested the fund in government securities, fixed deposits at commercial banks, shares and debentures, term loan etc. This scheme has guaranteed a minimum return to its investors.

Besides, Citizen Unit Scheme, CIT operates and manages various types of retirement schemes / programs as well as various unit schemes and mutual fund program, these are: are Employee Saving Growth Retirement Scheme, Gratuity and Pension Fund Scheme, and Insurance Schemes. It provides services for both domestic and foreign investors to encourage the people for saving in order to expand fund and increase the investment opportunities along with the dynamic development of the capital market to contribute economic development of the nation (www.nlk.org.np). However, this scheme is not tradable in NEPSE but popular among government employees and defensive investor who wants less risk but regular return (Rauniyar, 2016). Moreover, CIT, there are other nine mutual fund companies functioning in Nepal, i.e. NBL Capital Markets, Laxmi Capital Market, Global IME Capital (previously known as Elite Capital), Siddhartha Capital and NMB Capital (Eldrum, 2017).

\section{Review of Empirical Literatures}

Sahadevan and Thiripalraju (1997) have published a research work on "Mutual funds: Data, Interpretation and Analysis. The study provides a unique source for a critical analysis of the mutual funds regulation, and the reader gets a comprehensive picture of mutual funds regulation in comparison with the United States and the United Kingdom. It provides statistics relating to the performance of many mutual funds, both public and private sectors. This work is useful for fund managers, institutional investors, individual investors and merchant bankers, postgraduate students in finance, and researchers in mutual funds.

Kamiyama (2007) has carried out the study on "India's Mutual Fund Industry" including the main subjects: Overview of the mutual fund industry, the history of mutual funds, legal framework for mutual funds, mutual fund products, distribution- channel and assets management companies. The study highlights a number of barriers to the entry of foreigncapitalized assets management companies in India's mutual fund market and the biggest difficulty in the staffing of their sales operation.

The study of The World Bank (2015) entitled " Mutual Funds in Developing Markets: Addressing Challenges to Growth" provides policy makers in developing countries who seek to foster the domestic mutual fund sector with a handbook to understand the sector; it presents a range of legal/regulatory and market-related factors that drive or impede mutual funds. The objective of this report is to lay out salient features that help develop the mutual fund 
industry in developing countries and unlock some of the key drivers and impediments that typically assist or stunt their growth. Few reports so far are drawn on cross-country studies to examine developing country mutual fund sectors. This study explores the nature of mutual fund sectors in different developing countries and presents, through illustrative examples, the heterogeneity in characteristics that arise for mutual fund sectors developed in different geographic and economic contexts. The study focuses primarily on publicly offered, domestic mutual funds (legally domiciled in the host country in which they are primarily distributed). The study draws from five country case studies of mutual fund sectors conducted by the World Bank in 2012 - Brazil, Kenya, Morocco, Peru, and Turkey - and on various other examples (The World Bank [WB], 2015). The details of these studies are provided in the chapters that follow, using data and insights from the time of the respective case studies, with updated data where possible. The study also draws on a 2013 global survey conducted by the International Organization of Securities Commissions (IOSCO) on mutual fund markets in developing countries (WB, 2015). Throughout the report these case studies are referenced to depict the heterogeneity as well as similarities in trends of mutual fund sectors globally.

Joshi and Kaul (2016) have published the research report on "Mutual Fund Industry in India: Deloitte Perspective". In this report, they have brought together their expertise in the Indian regulatory and taxation landscape, and their experience of working on product innovation and distribution with Indian mutual funds. They expect that the report is insightful and innovative for the strategic decision of mutual fund sectors. They point out the mutual funds face a double challenge: firstly, increasing their share of the pie in the urban markets that have seen crowding of products and vendors, and secondly, capturing the attention of investors in suburban and rural markets that have been largely averse to complex financial instruments, and are often unreachable through traditional distribution channels. Mutual funds will have to leverage technology to drive innovation in products, and adopt alternate distribution channels to be successful in the Indian market.

Rauniyar (2016) has done a study on "Performance Evaluation of Nepalese Mutual Funds" by using secondary and primary data. The main objective of the study is to evaluate and compare the performance of closed end mutual fund scheme. Six running mutual funds schemes i.e. Siddhartha Investment Growth Scheme-1, Nabil Balance Fund- 1, NMB Sulav Investment Fund- 1, Siddhartha Equity Oriented Scheme, NIBL Samriddhi Fund- 1, Laxmi Value Fund1 and Global IME Samunat Yojana- 1 are included as sample schemes in this study. This study uses Treynor ratio return as dependent variable and assets, expenses, turnover, age, liquidity and lag of Treynor ratio return as independent variables. The result indicates that among various fund attributes lagged return, liquidity and asset have significant impact on mutual fund performance.

\section{Problems and Objectives}

To invest profitably in mutual funds, it is crucial to have investor's understanding of how stock and bond markets work. Investors need to know what causes prices to move and how to know when markets are cheap. The fact remains that, despite the introduction of a wide variety of mutual funds products to match the diverse risk return perception of the populace, 
they have hardly made any difference to the asset preferences in stock market. Too many people don't understand what they are buying - or even what they are paying with so many choices. Besides investing in inappropriate and high-cost portfolios, people also buy idle stocks. This has been further worsened by the lack of information (Fredman \& Wiles, 1997; Sahadevan \& Thiripalraju, 1997). There is no comprehensive information and data on mutual funds easily available till date in the mutual fund market in Nepal. That is why the paper "Current Status of Mutual Fund Schemes in Nepal" gives over so much attention to the different kinds of mutual fund schemes in Nepal. In these regards, the main objective of this paper is to provide necessary facts and figures relevant to the mutual fund schemes in Nepal. The specific objectives of the paper are to highlight the mutual fund schemes size, to analyze the market price of mutual fund schemes, and to identify the NAV and dividend distribution conditions of mutual fund schemes.

\section{Data and Methods}

This paper is based on secondary data collected through electronic media, and qualitative and quantitative data are used. Collected data are classified, categorized and tabulated, and analyzed according to the objectives of the paper. Simple mathematical tools, like average and percentage are used for the analysis of data.

\section{Discussions and Analysis}

\section{Mutual Fund Schemes in Nepal}

Table 1: Mutual Fund Schemes and their Managers

\begin{tabular}{lll}
\hline \multicolumn{1}{c}{ Symbol } & \multicolumn{1}{c}{ Mutual fund scheme } & \multicolumn{1}{c}{ Scheme manager } \\
\hline GIMES1 & Global IME Samunnat Scheme-1 & Global IME Capital Limited \\
LVF1 & Laxmi Value Fund-1 & Laxmi Capital Limited \\
NBF1 & Nabil Balance Fund-1 & Nabil Investment Banking Limted \\
NEF & Nabil Equity Fund & Nabil Investment Banking Limited \\
NIBLPF & NIBL Pragati Fund & NIBL Capital Market Limited \\
NIBSF1 & NIBL Samriddhi Fund-1 & NIBL Capital Market Limited \\
NMBHF1 & NMB Hybrid Fund L-1 & NMB Capital Limited \\
NMBSF1 & NMB Sulav Investment Fund-1 & NMB Capital Limited \\
SEOS & Siddhartha Equity Oriented Scheme & Siddhartha Capital Limited \\
SIGS1 & Siddhartha Investment Growth Scheme-1 & Siddhartha Capital Limited \\
\hline
\end{tabular}

Source: Eldrum (as cited in Sharma, 2017); IMS Investment Management Service, 2017

There are ten mutual fund schemes listed and traded in Nepal Stock Exchange (NEPSE), as shown in Table 1. These schemes are managed by different scheme managers. The scheme manager of Global IME Samunnat Scheme-1 is Global IME Capital Limited, Laxmi Value Fund-1 is Laxmi Capital Limited, Nabil Balance Fund-1 and Nabil Equity Fund is Nabil 
Investmen Banking Limited, NIBL Pragati Fund and NIBL Samriddhi Fund-1 is NIBL Capital Market Limited, NMB Sulav Investment Fund-1 and NMB Hybrid Fund L-1 is NMB Capital Limited, and Siddhartha Equity Oriented Scheme and Siddhartha Investment Growth Scheme-1 is Siddhartha Capital Limited (Table 1).

\section{Maturity of Mutual Fund Schemes}

Table 2 shows that Nabil Equity Fund, NIBL Pragati Fund, NIBL Sambriddi Fund-1 and NMB Hybrid Fund L-1 have seven years of maturity. Similarly Global IME Samunnat Scheme-1, Laxmi Value Fund 1, Nabil Balance Fund 1, NMB Sulav Investment Fund-1, Siddhartha Equity Oriented Scheme and Siddhartha Investment Growth Scheme have five years of maturity. The average maturity period of the fund schemes is 5.8 years. Similarly the minimum and maximum maturity periods are 5 years and 7 years respectively.

Table 2: Maturity of Mutual Fund Schemes

\begin{tabular}{llc}
\hline \multicolumn{1}{c}{ Mutual fund scheme } & \multicolumn{1}{c}{ Maturity date } & Maturity period (in years) \\
\hline Global IME Samunnat Scheme- 1 & March 24, 2021 & 5 \\
Laxmi Value Fund-1 & March 25, 2020 & 5 \\
Nabil Balance Fund-1 & April 11, 2018 & 5 \\
Nabil Equity Fund & November 6, 2023 & 7 \\
NIBL Pragati Fund & January 11, 2023 & 7 \\
NIBL Sambriddi Fund-1 & January 7, 2022 & 7 \\
NMB Hybrid Fund L-1 & October 26, 2023 & 7 \\
NMB Sulav Investment Fund-1 & October 20, 2019 & 5 \\
Siddhartha Equity Oriented Scheme & July 22, 2019 & 5 \\
Siddhartha Investment Growth Scheme-1 & December 24, 2017 & 5 \\
\hline
\end{tabular}

Source: IMS Investment Management Service, 2017; Sharma, 2017

\section{Fund Size and Market Price of Mutual Fund Schemes}

Table 3 indicates the initial funds size of Nabil Equity Fund is Rs 1250 millions, Global IME Samunnat Scheme-1, NIBL Sambriddi Fund-1, NMB Hybrid Fund L-1 and Siddhartha Equity Oriented Scheme have equal amount i.e., Rs 1000 million of each. Likewise the funds size of Nabil Balance Fund-1, NIBL Pragati Fund and NMB Sulav Investment Fund 1 are of Rs 750 millions. Rest schemes Laxmi Value Fund-1 and Siddhartha Investment Growth Scheme-1 has Rs 500 millions. The table also indicates that the total fund size of mutual fund schemes is Rs 8500 million. The maximum fund size of mutual fund schemes is Rs 1250 million, minimum fund size is Rs 500 million and average fund size is Rs 850 million. 
Table 3: Initial Fund Size of Mutual Fund Schemes

\begin{tabular}{lcc}
\hline \multicolumn{1}{c}{ Schemes } & Initial Fund size (Million Rs) & Percentage \\
\hline Global IME Samunnat Scheme-1 & 1000 & 11.76 \\
Laxmi Value Fund-1 & 500 & 5.88 \\
Nabil Balance Fund-1 & 750 & 8.83 \\
Nabil Equity Fund & 1250 & 14.71 \\
NIBL Pragati Fund & 750 & 8.83 \\
NIBL Sambriddi Fund-1 & 1000 & 11.76 \\
NMB Hybrid Fund L-1 & 1000 & 11.76 \\
NMB Sulav Investment Fund-1 & 750 & 8.83 \\
Siddhartha Equity Oriented Scheme & 1000 & 11.76 \\
Siddhartha Investment Growth Scheme-1 & 500 & 5.88 \\
Total & 8500 & 100 \\
\hline
\end{tabular}

Source: IMS Investment Management Service, 2017; Sharma, 2017

Table 4: Par Value and Market Price Mutual Fund Schemes (Rs)

\begin{tabular}{lccc}
\hline \multicolumn{1}{c}{ Scheme } & $\begin{array}{c}\text { Par } \\
\text { value }\end{array}$ & $\begin{array}{c}\text { Market price } \\
\text { as of } \\
2017-06-25\end{array}$ & $\begin{array}{c}\text { 180 days average } \\
\text { market price up to } \\
2017-06-25\end{array}$ \\
\hline Global IME Samunnat Scheme-1 $^{*}$ & 10 & 9.79 & 10.03 \\
Laxmi Value Fund-1 & 10 & 12.50 & 11.78 \\
Nabil Balance Fund-1 & 10 & 19.21 & 18.75 \\
Nabil Equity Fund & 10 & 9.80 & 10.13 \\
NIBL Pragati Fund & 10 & 9.90 & 10.06 \\
NIBL Sambriddi Fund-1 & 10 & 12.00 & 11.66 \\
NMB Hybrid Fund L-1 & 10 & 9.81 & 10.08 \\
NMB Sulav Investment Fund-1 & 10 & 12.60 & 14.55 \\
Siddhartha Equity Oriented Scheme & 10 & 11.85 & 11.90 \\
Siddhartha Investment Growth Scheme-1 & 10 & 23.05 & 22.76
\end{tabular}

*Last traded on 2017/06/21 03:00:00

Source: IMS Investment Management Service, 2017; Mero Lagani, 2017; Sharma, 2017; http://merolagani.com/StockQuote.aspx

Table 4 indicates per unit par values, per unit market prices (as of 2017-06-25) and per unit average market prices (180 days average market price up to 2017-06-25) of the mutual fund schemes. The per unit par value of ten mutual fund schemes are equal (Rs 10 per unit). Per unit market price (Rs 23.05) and average market price (Rs 22.76) of Siddhartha Investment Growth Scheme-1 are the largest than other schemes, and per unit market price (9.73) and average market price (10.03) of Global IME Samunnat Scheme-1 are the lowest. Per unit market value of mutual funds schemes ranges between Rs. 9.79 to 23.05 (as of 2017-5-25). 180 days per unit average market price (up to 2017-5-25) of mutual funds schemes ranges between Rs 10.03 to Rs 22.76 . 


\section{Net Asset Value and Cash Dividend of Mutual Fund Schemes}

Table 5 shows that the weekly NAV, Monthly NAV and cash dividend distribution position of mutual fund schemes. Among ten mutual fund schemes, weekly NAV (Rs 26.65) and monthly NAV (Rs 27.28) of Siddhartha Investment Growth Scheme-1 are the highest NAV. Similarly, cash dividend (60\%) of Siddhartha Investment Growth Scheme-1 is higher than other schemes. The table also shows that Weekly (Rs 9.98) and Monthly (10.11) both NAV of Nabil Equity fund are lower than other fund schemes, and NIBL Sambriddi Fund-1 distributed lowest cash dividend (18\%) than other fund schemes. Because of their short time of establishment, four mutual fund schemes, i.e. Global IME Samunnat Scheme-1, Nabil Equity Fund, NIBL Pragati Fund and NMB Hybrid Fund L-1 did not distribute dividends of FY 2016-2017.

Table 5: Net Assets Value and Cash Dividend of Mutual Fund Schemes (Rs.)

\begin{tabular}{lccc}
\hline \multicolumn{1}{c}{ Schemes } & & Monthly NAV & \\
& Weekly NAV & $(2017-04-14$ to & Cash Dividend \\
& $(2017-06-16)$ & $2017-05-13)$ & (FY 2016-017) \\
\hline Global IME Samunnat Scheme-1 & 10.23 & 10.39 & NA \\
Laxmi Value Fund-1 & 13.75 & 13.61 & $25 \%$ \\
Nabil Balance Fund-1 & 24.08 & 24.53 & $42 \%$ \\
Nabil Equity Fund & 9.98 & 10.11 & $\mathrm{NA}$ \\
NIBL Pragati Fund & 10.00 & 10.37 & $\mathrm{NA}$ \\
NIBL Sambriddi Fund-1 & 15.13 & 15.46 & $18 \%$ \\
NMB Hybrid Fund L-1 & 10.44 & 10.46 & $\mathrm{NA}$ \\
NMB Sulav Investment Fund-1 & 16.80 & 17.01 & $21 \%$ \\
Siddhartha Equity Oriented Scheme & 15.11 & 15.41 & $25 \%$ \\
Siddhartha Investment Growth Scheme-1 & 26.65 & 27.28 & $60 \%$ \\
\hline
\end{tabular}

Source: Budhathoki, 2017; Eldrum, 2017; IMS Imvestment Management Service, 2017; Sharma, 2017

\section{Summary and Conclusion}

Mutual funds are financial intermediaries who collect the saving of small investors and invest them in a large and well diversified portfolio of securities. Such portfolio of securities includes money market instruments, corporate and government bonds and equity shares of joint stock companies. A mutual fund is pools of funds invested by different investors who have to contact with other small investor also generally do not have adequate time, expert knowledge, experience and resources for directly accessing the capital market.

There is no long history of mutual fund market in Nepal and only ten mutual fund schemes are currently listed and traded in NEPSE. These schemes are run by collecting initial funds Rs 8500 million. The maximum mutual fund scheme size is Rs 1250 million and minimum mutual fund schemes size is Rs. 500 million. The maximum maturity period of mutual funds 
schemes is seven years, minimum maturity period is five years and average maturity period is 5.8 years. Per unit par values of all ten mutual fund schemes are Rs. 10. 180 days average market price of all the mutual fund schemes is higher than par value. Among ten mutual fund schemes, a market price of six mutual fund scheme is higher than par value, and the market price of four schemes is lower than par value.

Regarding the weekly NAV of Mutual fund schemes, Siddhartha Investment Growth Scheme-1 has highest weekly NAV (Rs 26.65) and Nabil Equity Fund has low weekly NAV (Rs 9.98). Similarly, Siddhartha Investment Growth Scheme-1 has highest monthly NAV (Rs 27.28) and Nabil Equity Fund has lowest monthly NAV (Rs 10.11). About the latest dividend distribution, Siddhartha Investment Growth Scheme-1 distributed (60\%) cash dividend that is highest cash dividend; NIBL Sambriddi Fund-1 distributed lowest (18\%). Among these ten mutual fund schemes, four schemes did not distribute cash dividends because of their short period of establishment.

The market price (as of 2017-06-25) of Global IME Samunnat Scheme-1 (Rs 9.79), Nabil Equity Fund (Rs 9.80) and NIBL Pragati Fund (9.90) is less than the par value (Rs. 10). Therefore, the market price of these schemes should be improved. As the NAV of Nabil Equity Fund is lower than the other schemes, it should be increased. NIBL Sambriddi Fund-1 has distributed lowest latest dividends. So the profit of this fund should be improved.

\section{BIBLOGRAPHY}

Alexander, G. J., Sharpe, W. F., \& Bailey, J. V. (2002). Fundamentals of investment (3rd ed.). New Delhi: Prentice-Hall of India.

Bodie, Z., Kane, A., \& Marcus, A. J. (1995). Essentials of investments. Chicago: IRWIN.

Budhathoki, P. (2017, October 15). Samuhik lagani koshko aakarshak pratiphal [Attractive return on mutual fund]. Arthik Abhiyan, P. 1.

Cheney, J. M., \& Moses, E. A. (1992). Fundamentals of investments. St. Paul: West Publishing Company.

Fabozzi, F. J. (1995). Investment management. New Jersey: Prentice Hall.

Fredman, A. J., \& Wiles, R. (1997). How mutual funds work. New Delhi: Prentice-Hall of India. Eldrum, R. (2017). 10 mutual funds you can buy in Nepal. Retrieved from https://toughnickel. com/personal-finance/Mutual-Funds-in-Nepal

IMS Investment Services. (2017). Mutual funds and NAVs. Kathmandu: Author. Retrieved June 26, 2017, From http://www.sharesansar.com/c/mutual-fund-navs.html

Indian Chamber of Commerce. (2016). Mutual fund industry in India: Deloitte Perspective. 
Kolkata: Auther.

Joshi, G., \& Kaul, S. S. (2016). Mutual fund industry in India: Deloitte perspective. Kolkata: Indian Chamber of Commerce.

Kamiyama,T.(2007). India'smutual fundindustry. Nomura CapitalMarketReview, 10(4),57-72.

Mero Lagani. (2017). Laxmi value fund- 1. Retrieved June 26, 2017, From http://merolagani. com/CompanyDetail.aspx?symbol=LVF1

Rauniyar, A. (2016). Performance evaluation of Nepalese mutual funds. Unpublished MPhil's research paper, Kathmandu University School of Management, Kathmandu University.

Sahadevan, K. G., \& Thiripalraju, M. (1997). Mutual funds: Data, interpretation and analysis. New Delhi: Prentice-Hall of India.

Sharma, D. R., Thapa, K., Pandeya, C., Joshi, R, \& Lamsal, B. P. (2016). Fundamentals of investment. Kathmandu: Khanal Publication.

Sharma, S. (2017). A study of mutual fund schemes in Nepal. Unpublished master's thesis, Prithivi Narayan Campus, Tribhuvan University

Shrestha, M. K., Poudel, R. B., \& Bhandari, D. B. (2005). Fundamentals of investments ( $2^{\text {nd }}$ ed.). Kathmandu: Buddha Academic Publishers and Distributors.

The World Bank. (2015). Mutual funds in developing markets: Addressing challenges to growth. Washington DC: Author. 